http://dx.doi.org/10.11646/phytotaxa.173.4.2

\title{
A new species of Miconia (Miconieae, Melastomataceae) from the Brazilian Amazon
}

\author{
JULIA MEIRELLES ${ }^{1} \&$ RENATO GOLDENBERG ${ }^{2}$ \\ ${ }^{1}$ Universidade Estadual de Campinas, Pós-Graduação em Biologia Vegetal. Cidade Universitária Zeferino Vaz, 13083-970, Campinas, \\ São Paulo, Brazil.E-mail: jmeirell@gmail.com \\ ${ }^{2}$ Universidade Federal do Paraná, Departamento de Botânica, Centro Politécnico, Caixa Postal19031 CEP 81531-970 \\ Curitiba,Paraná, Brazil.E-mail: rgolden@ufpr.br
}

\begin{abstract}
A new species of Miconia sect. Miconia subsection Seriatiflorae. was collected in Igapó Forest from the Purus-Madeira interfluve, in the state of Amazonas, Brazil. This new species, Miconia suberosa, can be distinguished from other species in the subsection by a variety of morphological features, namely: (i) treelet habit; (ii) deeply fissured bark with a thick cork; (iii) long dendritic hairs with short arms on young branches, inflorescences and leaves; (iv) petiolated leaves with rounded to obtuse bases, and ciliate margins, congested at the branch apices; and, (v) truncated stigmas.
\end{abstract}

\section{Resumo}

Uma nova espécie de Miconia sect. Miconia subsect. Seriatiflorae foi coletada em floresta de Igapó no interflúvio PurusMadeira no estado do Amazonas, Brasil. Esta nova espécie, Miconia suberosa, distingue-se dentre as demais espécies da subseção por várias características morfológicas, especialmente: (i) hábito arvoreta; (ii) tronco profundamente fissurado com espessa camada de súber; (iii) longos tricomas dentríticos com braços curtos sobre os ramos jovens, inflorescências e folhas; (iv) folhas pecioladas com base arredondada a obtusa e margens ciliadas, congestas nos ápices dos ramos; e, (v) estigmas truncados.

\section{Introduction}

Miconia Ruiz \& Pavón (1794: 60) includes 1057 species, constituting the largest genus of Melastomataceae (Goldenberg et al. 2013). The genus belongs to the Tribe Miconieae which is characterized by fleshy fruits and inferior ovaries (Michelangeli et al. 2004). Species of the genus are shrubs, treelets, or trees, rarely climbers, ranging from western Mexico and the Caribbean to Uruguay and northern Argentina, growing from sea level to the Andean Paramos (Goldenberg et al. 2008). The genus can be recognized by the terminal inflorescences, rounded, obtuse or retuse petals, and lack of ant domatia, among others (Cogniaux 1891, Goldenberg 2000). The high levels of homoplasy encountered in the genus and close relatives involves overlapping patterns of morphological variation that have led to a complicated generic circumscription in this group (Judd \& Skean 1991).

In Brazil, the genus is most diverse in the Amazon, where more than half of its species occur (ca.166 of the 300 Brazilian species) (Goldenberg et al. 2013). Despite the constant efforts to document and inventory the Amazonian Flora (Black et al. 1950, Pires et al. 1953, Ter Steege et al. 2013), western Brazilian Amazon remains as a major gap in botanical knowledge, likely containing many undescribed species (Hopkins 2007). In particular, the interfluve between the Purus and Madeira rivers has yielded many recent discoveries, including new genera and species of fishes (Bührnheim et al. 2008), mammals (Roosmalen et al. 2002), and a new record for the angiosperm family Tetrameristaceae, previously only known from Venezuela (Viana et al. 2010). The new species of Miconia described here was first collected in the 1970's along the BR-319 highway, between Manaus and Porto Velho; however, these earlier specimens lacked flowers, complicating the identification of this taxon. Recent new collections from this same species allowed us to study this taxon in further detail and confirm its identity. 


\section{References}

Bentham, G. (1850) Report on the plants collected by Mr. Spruce at Pará. Hooker's Journal of Botany and Kew Garden Miscellany 2: 241.

Black, G. A., Dobzhansky, T. H., Pavan, C. (1950) Some attempts to estimate species diversity and population density of trees in Amazonian forests. Botanical Gazette 111 (4), 413: 413-425. http://dx.doi.org/10.1086/335612

Bührnheim, C. M., Carvalho, T.P., Malabarba, L.R. \& Weitzman, S.H. (2008) A new genus and species of characid fish from Amazon basin - the recognition of a relictual lineage of characid fishes (Ostariophysi: Cheirodontinae: Cheirodontini). Neotropical Ichthyology 6: 663-678. http://dx.doi.org/10.1590/s1679-62252008000400016

Cogniaux, C.A. (1886) Melastomaceae. In: Martius, C.F.P. \& Eichler, A.W. (Eds.) Flora Brasiliensis 14 (4). Fleischer, Leipzig, 655 pp. Cogniaux, A.C. (1891) Melastomataceae. In: A. P. de Candolle \& C. de Candolle (Eds.) Monographiae phanerogamarum 7: 1-1256. G. Masson, Paris.

De Candolle, A.P. (1828) Prodromus Systematis Naturalis Regni Vegetabilis. Tom. I et II. Paris.

Fearnside, P.M. \& Graça, P.M.L.A. (2009) BR-319: A Rodovia Manaus-Porto Velho e o impacto potencial de conectar o arco de desmatamento à Amazônia central. Novos Cadernos NAEA. 12: 19-50.

Goldenberg, R. (2000) O gênero Miconia Ruiz \& Pav. Melastomataceae. I. Listagens analíticas. II. Revisão taxonômica da seção Hypoxanthus (Rich. ex DC.) Hook. F. Ph.D. dissertation. Universidade Estadual de Campinas, Campinas, Brazil.

Goldenberg, R., Penneys, D.S., Almeda, F., Judd, W.S. \& Michelangeli, F.A. (2008) Phylogeny of Miconia (Melastomataceae): patterns of stamen diversification in a megadiverse neotropical genus. International Journal of Plant Sciences 169: 963-979. http://dx.doi.org/10.1086/589697

Goldenberg, R., Almeda, F., Caddah, M.K., Martins, A.B., Meirelles, J., Michelangeli, F.A. \& Weiss, M. (2013) Nomenclator botanicus for the neotropical genus Miconia (Melastomataceae: Miconieae). Phytotaxa 106: 1-171. http://dx.doi.org/10.11646/phytotaxa.106.1.1

Goldenberg, R, Baumgratz, J.F.A. \& Souza, M.L.R. (2012) Taxonomia de Melastomataceae no Brasil: retrospectiva, perspectivas e chave de identificação para os gêneros. Rodriguésia 63: 145-161. http://dx.doi.org/10.1590/s2175-78602012000100011

Hopkins, M.J.G. (2007) Modelling the known and unknown plant biodiversity of the Amazon Basin. Journal of Biogeography 34: 14001411. http://dx.doi.org/10.1111/j.1365-2699.2007.01737.x

IUCN (2014) IUCN Standards and Petitions Subcommittee. 2014. Guidelines for Using the IUCN Red List Categories and Criteria. Version 11. Prepared by the Standards and Petitions Subcommittee. Downloadable from http://www.iucnredlist.org/documents/ RedListGuidelines.pdf.

Judd, W.S. \& Skean, J.D. (1991) Taxonomic studies in the Miconieae (Melastomataceae). IV. Generic realignments among terminalflowered taxa. Bulletin of the Florida Museum of Natural History 36: 25-84.

Kriebel, R. \& Almeda, F. (2013) Two new species of Miconia (Melastomataceae: Miconieae) from the cloud forests of Panama. Phytotaxa 13: $27-41$. http://dx.doi.org/10.11646/phytotaxa.134.1.2

Michelangeli, F.A., Penneys, D.S., Giza, J., Soltis, D., Hils, M.H. \& Skean, J.D. (2004) A preliminary phylogeny of the tribe Miconieae (Melastomataceae) based on nrITS sequence data and its implications on inflorescence position. Taxon 53: 279-290. http://dx.doi.org/10.2307/4135608

Michelangeli, F.A. (2010) Neotropical Myrmecophilous Melastomataceae an annotated list and key. Proceedings of California Academy of Sciences 4: 409-449.

Naudin, C.V. (1849-1853) Melastomacearum monographicae descriptionis. Annales des Sciences Naturelles, Botanique, Series III, tom, xii-xviii, consolidated reprint.

Ocampo, G. \& Almeda, F. (2013) Seed diversity in the Miconieae (Melatomataceae): morphological characterization and phenetic relationships. Phytotaxa 80: 1-129. http://dx.doi.org/10.11646/phytotaxa.80.1.1

Pires, J.M., Dobzhansky, T. \& Black G.A. (1953) An estimate of the number of species of trees in an Amazonian forest community. Botanical Gazette 114 (4): 467-477. http://dx.doi.org/10.1086/335790 
Roosmalen, M.G.M. van, Roosmalen, T. van \& Mittermeier, R.A. (2002) A taxonomic review of the titi monkeys, genus Callicebus Thomas, 1903, with the description of two new species, Callicebus bernhardi and Callicebus stephennashi, from Brazilian Amazonia. Neotropical Primates 10: 1-52.

Ruiz, D.H. \& Pavón D.J. (1794) Florae Peruvianae, et Chilensis Prodromus. Imprenta de Sancha, Madrid, 153 pp. http://dx.doi.org/10.5962/bhl.title.11759

Viana, P.L., Carvalho, F.A. \& Silva, I.R. (2010) Tetrameristaceae (Angiospermae: Ericales): primeiro registro da família para o Brasil. Revista Brasileira de Botânica 33: 375-378.

http://dx.doi.org/10.1590/s0100-84042010000200018 